\title{
Pengembangan Media Pembelajaran Matematika Berbasis Macromedia Flash Materi Luas dan Keliling untuk Meningkatkan Motivasi Belajar Siswa
}

\author{
Krisma Widi Wardani, Danang Setyadi \\ krisma.widi@uksw.edu, danang.setyadi@uksw.edu \\ Pendidikan Guru Sekolah Dasar, FKIP, Universitas Kristen Satya Wacana \\ Pendidikan Matematika, FKIP, Universitas Kristen Satya Wacana \\ Development of Macromedia Flash-Based Mathematics Learning Media \\ for Area and Circumference Material to Increase Student Learning Motivation
}

\begin{abstract}
One of the computer-based mathematics learning media developed is Macromedia Flash-based learning media. Macromedia Flash-based learning media that have been available so far have not been students to be actively involved in using the media. This has encouraged researchers to develop new Macromedia Flash-based media. This research is development research. The development model used in 4D, namely Defines, Design, Develop and Disseminate. The subjects consisted of 60 students in grade 4 at SD Mardirahayu 01 and 02 Ungaran. The research instrument consisted of media validation sheets, material validation sheets, student response sheets, and motivation questionnaires. Research data were analyzed qualitatively and quantitatively. The results showed that the media developed were valid and could increase students' motivation in learning mathematics in a broad and mobile material.
\end{abstract}

Keywords: Learning Media, Luas dan Keliling, Macromedia Flash

\section{Article Info}

Received date: 12 Desember 2019
Revised date: 7 Januari 2020
Accepted date: 22 Januari 2020

\section{PENDAHULUAN}

Keberhasilan peserta didik dalam belajar matematika dipengaruhi oleh berbagai faktor (Umam \& Yudi, 2016; Astuti \& Leonard, 2012), salah satunya adalah media pembelajaran yang digunakan oleh guru dalam proses pembelajaran (Khairani \& Febrinal, 2016; Ahern, 2016). Dalam pembelajaran matematika, media berperan untuk membantu peserta didik dalam memahami konsep yang diberikan, memotivasi peserta didik untuk belajar, dan membuat suasana kelas menjadi tidak monoton (Anggani, 2000; Amir, 2014; Wicaksono, 2016; Setyadi \& Qohar, 2017).

Seiring kemajuan teknologi, media pembelajaran matematikapun bervariasi. Banyak media pembelajaran matematika mulai dikembangkan dengan menggunakan komputer, diantaranya adalah media pembelajaran matematika berbasis Macromedia Flash (Tyanto \& Manoy, 2013; Waskito 2014).

Macromedia Flash merupakan software yang dikembangkan oleh Adobe. Software ini dapat digunakan untuk animasi, game, dan aplikasi pengayaan internet yang dapat dijalankan pada perangkat yang memiliki aplikasi adobe flash player (Kusumadewi, 2013; Sukamto, 2015; Khairani \& Febrinal, 2016).

Penggunaan media pembelajaran matematika berbasis Macromedia Flash memiliki beberapa keunggulan, diantaranya membantu guru dalam menyiapkan bahan ajar dan menyelenggarakan pembelajaran, meningkatkan kemampuan komunikasi matematik peserta didik, memvisualisasikan materi belajar yang bersifat abstrak menjadi lebih real, dan meningkatkan pemahaman konsep peserta didik (Masykur, Nofrizal, \& Syazali 2017; Sinurat, Syahputra, \& Rajagukguk, 2015; Arda \& Darsikin, 2015; Khairani \& Febrinal, 2016 )

Terdapat beberapa penelitian tentang pengembangan media pembelajaran berbasis Macromedia Flash pada materi luas dan keliling, diantaranya penelitian yang dilakukan oleh Safitri (2013) dan Putra \& Manoy (2016). Namun demikian, media pembelajaran matematika berbasis Macromedia Flash yang dikembangkan beberapa peneliti tersebut masih memiliki beberapa 
Pengembangan Media Pembelajaran Matematika Berbasis Macromedia Flash Materi Luas Dan

Keliling Untuk Meningkatkan Motivasi Belajar Siswa (Krisma Widi Wardani, Danang Setyadi)

kelemahan, yaitu belum mampu mengaktifkan peserta didik. Hal tersebut terjadi karena media yang dikembangkan hanya memberikan pilihan untuk memiih jawaban atau membaca materi. Media yang dikembangkan belum memungkinkan peserta didik melakukan aktivitas melalui media tersebut, misalnya menginput jawaban atau memberikan alasan terhadap jawaban yag dipilih.

Berdasarkan hal tersebut, peneliti tertarik untuk mengembangkan media pembelajaran berbasis Macromedia Flash yang memungkinkan terjadinya interaksi antara peserta didik dengan media yang dikembangkan.

\section{KAJIAN PUSTAKA}

\section{Motivasi Belajar}

Pada dasarnya motivasi adalah suatu usaha yang disadari untuk menggerakkan, menggarahkan dan menjaga tingkah laku seseorang agar ia terdorong untuk bertindak melakukan sesuatu sehingga mencapai hasil atau tujuan tertentu (Hamdu \& Agustina, 2011). Sardiman (2011) mendefinisikan motivasi sebagai keseluruhan daya penggerak dalam diri siswa yang menimbulkan kegiatan belajar, yang menjamin kelangsungan dari kegiatan belajar dan yang memberikan arah pada kegiatan belajar, sehingga tujuan yang dikehendaki oleh subjek belajar itu dapat tercapai. Motivasi belajar adalah proses yang memberi semangat belajar, arah dan kegigihan perilaku (Agus Suprijono, 2009). Winkel (1983) Motivasi belajar adalah keseluruhan daya penggerak di dalam diri siswa yang menimbulkan kegiatan serta memberi arah pada kegiatan belajar. Dapat disimpulkan bahwa motivasi belaajr adalah penggerak yang ada di dalam diri siswa yang memberi semangat untuk bertindak dan melakukan sesuatu sehingga dapat mencapai tujuan.

\section{Matematika SD}

Sepintas konsep matematika yang diberikan pada siswa Sekolah Dasar (SD) sangatlah sederhana dan mudah tetapi sebenarnya materi matematika memuat konsep-konsep mendasar dan penting serta tidak boleh dipandang gampang. Diperlukan kecermatan dalam menyajikan konsepkonsep tersebut agar siswa mampu memahaminya secara benar, sebab kesan dan pandangan yang diterima siswa terhadap suatu konsep di sekolah dasar dapat terus terbawa pada masa-masa selanjutnya. Kesan pertamakali yang ditangkap oleh siswa akan terus terekam dan menjadi pandangannya di masamasa selanjutnya (Prihandoko, 2006). Pemerintah menetapkan usia minimal siswa Sekolah Dasar adalah 6 atau 7 tahun, dengan masa studi 6 tahun maka rentang usia siswa SD yaitu 6 atau 7 Tahun hingga 12 atau 13 tahun. Menurut Piaget usia tersebut masuk dalam fase operasional konkret. Menurut usia perkembangan kognitif siswa di usia ini masih terikat dengan objek konkret yang dapat ditangkap oleh panca indra. Dalam pembelajaran matematika yang abstrak, siswa memerlukan alat bantu berupa media dan alat peraga yang dapat memperjelas apa yang akan disampaikan oleh guru, sehingga lebih cepat dipahami dan dimengerti siswa (Wardani, 2012).

Wardani, 2012 juga menyebutkan bahwa tujuan akhir pembelajaran Matematika di SD yaitu agar siswa terampil dalam menggunakan berbagai konsep matematika dalam kehidupan sehari-hari. Untuk sampai pada tahap terampil ada beberapa fase yang perlu di lalui yaitu 1) Penanaman Konsep dasar, dengan menggunakan media atau alat peraga untuk dapat membantu pola pikir siswa. 2) Pemahaman Konsep, merupakan kelanjutan dari penanaman konsep, atau dapat dilakukan pada pertemuan berbeda tetapi masih merupakan lanjutan dari pemahaman konsep. 3) Pembinaan Ketrampilan merupakan pembelajaran lanjutan dari penanaman konsep dan pemahaman konsep.

\section{Media Pembelajaran berbasis Macromedia Flash}

Macromedia Flash adalah platform multimedia dan perangkat lunak yang digunakan untuk pembuatan animasi, game dan aplikasi pengayaan internet yang dapat dilihat, dimainkan, dan dijalankan di Adobe Flash Player (Masykur, Nofrizal, \& Syazali 2017) Pemanfaatan Macromedia Flash sebagai media pembelajaran dijadikan sebagai alat bantu dalam menyampaikan materi ajar dan menyelenggarakan pembelajaran. Media ini juga dapat memancing stimulus siswa agar dapat memanipulasi konsep-konsep serta dapat mengetahui bentuk nyata konsep matematika yang abstrak (Yudi, 2016). 


\section{METODE PENELITIAN}

Penelitian ini adalah penelitian pengembangan. Media pembelajaran Matematika berbasis Macromedia Flash dalam penelitian ini dikembangkan dengan menggunakan model pengembangan yang digunakan adalah model 4D. Model 4D terdiri dari empat tahap, yaitu: Define (pendefinisian), Design (perancangan), Develop (pengembangan), dan Disseminate (penyebaran) (Thiagarajan, Semmel dan Semmel, 1974: 5). Model tersebut dimodifikasi yang dilakukan meliputi: 1) Tahap pendefinisian digunakan untuk mengumpulkan berbagai informasi yang berkaitan dengan produk yang akan dikembangkan. Tahap ini terdiri dari beberapa langkah, yaitu: analisis awal, analisis peserta didik, analisis tugas, dan analisis konsep. 2) Pada tahap perancangan, dilakukan pembuatan desain awal media yang akan dikembangkan. 3) Tahap pengembangan terdiri dari tahap validasi media dan tahap uji coba media. Validasi media terdiri dari validasi media dan validasi materi. Validasi media dilakukan pada aspek tampilan dan aspek tulisan. 4) Pada tahap ini, media yang telah dikembangkan disebarluaskan atau dipromosikan ke sekolah.

Pada tahap ke 3 yaitu pengembagan salah satu tahapannya adalah tahap validasi media dimana instrumen penelitian terdiri dari lembar validasi media dan lembar validasi materi yang dilakukan oleh pakar materi matematika dan pakar media terkait aspek tampilan dan aspek tulisan. Pada tahap uji coba, dilakukan di SD Mardirahayu 01 dan 02 Ungaran dengan subjek terdiri dari 60 peserta didik kelas 4 dan memberikan angket respon siswa di akhir kegiatan pembelajaran. Data hasil penelitian dianalisis secara kualitatif dan kuantitatif. Analisis kualitatif digunakan untuk mendeskripsikan media yang dikembangkan sedangkan analisis kuantitatif digunakan untuk mengetahui kevalidan media dan pendapat respon siswa.

\section{HASIL PENELITIAN DAN PEMBAHASAN}

\section{Tahap Pendefinisian (Define)}

Pada tahap pendefinisian ini dilakukan proses mengumpulkan berbagai informasi yang berkaitan dengan produk yang akan dikembangkan. Tahap ini terdiri dari beberapa langkah, yaitu: analisis awal, analisis peserta didik, analisis tugas, dan analisis konsep.

Analisis awal dilakukan untuk mengetahui permasalahan dasar dalam pengembangan media pembelajaran berbasis Macromedia Flash

Analisis peserta didik dilakukan dengan cara mengamati karakteristik peserta didik yang meliputi karakteristik kemampuan akademik, usia, dan motivasi terhadap mata pelajaran. Berdasarkan teori perkembangan, siswa kelas 4 SD rata-rata berusia 9-10 tahun dimana pada usia tersebut menurut piaget termasuk dalam fase operasional konkrit. Menurut usia perkembangan kognitif siswa di usia ini masih terikat dengan objek konkret yang dapat ditangkap oleh panca indra (Wardani, 2012). Agar kegiatan pembelajaran dapat berlangsung efektif, interaktif, inspiratif, menyenangkan, menantang, peserta didik maka perlu sesuatu yang dapat ditangkap oleh panca indra peserta didik yang akan dapat menumbuhkan motivasi dalam belajar.

Analisis tugas bertujuan untuk menganalis tugas-tugas utama yang akan dilakukan peserta didik. Analisis tugas terdiri dari analisis terhadap kompetensi inti (KI) dan kompetensi dasar (KD) terkait materi yang akan dikembangkan. Adapun kompetensi inti 3 Matematika kelas 4 yaitu memahami pengetahuan factual dengan cara mengamati dan menanya berdasarkan rasa ingin tahu tentang dirinya, makhluk ciptaan Tuhan dan kegiatannya, dan benda-benda yang dijumpai di rumah, di sekolah dan di tempat bermain. Sedangkan kompetensi dasar yang akan di capai yaitu KD 3.9 Menjelaskan dan menentukan keliling dan luas persegi, persegi panjang, dan segitiga serta hubungan akar pangkat dua. Pada tahap ini diputuskan bahwa materi yang digunakan adalah luas dan keliling. Selanjutnya, analisis konsep bertujuan untuk menentukan isi materi dari media yang akan dikembangkan. Untuk sampai pada tujuan pembelajaran memahami dan mampu menjelaskan luas dan keliling maka perlu dirancang pembelajaran yang terdiri dari 3 fase yaitu 1) Penanaman Konsep dasar, dengan menggunakan media atau alat peraga untuk dapat membantu pola pikir siswa 2) Pemahaman Konsep 3) Pembinaan Ketrampilan (Wardani, 2012) 


\section{Tahap Perancangan (Design)}

Pada tahap perancangan, dilakukan pembuatan desain awal media yang akan dikembangkan. Pada tahap ini, peneliti mulai merancang isi dari media (game), alur game, dan tokoh atau karakter yang akan digunakan dalam game.

Isi dari media terdiri dari materi dan latihan soal tentang luas dan keliling persegi, persegi panjang, dan segitiga. Alur yang digunakan adalah 'jelajah', artinya peserta didik harus belajar tentang luas dan keliling terlebih dahulu sebelum mencoba mengerjakan latihan soal yang diberikan. Selanjutnya, alur game tersebut dikombinasikan dengan pemilihan tiga tokoh karakter yang terdiri dari pria dan wanita yang bertugas untuk menuntun alur cerita game. Berikut adalah penjelasan tentang media yang dikembangkan:

\section{Halaman Awal}

Halaman awal berisi informasi tentang nama game yang dikembangkan. Berdasarkan Gambar 1, terlihat bahwa nama media ini adalah 'LuKel' yang merupakan akronim dari luas dan keliling.

2. Penyajian Materi

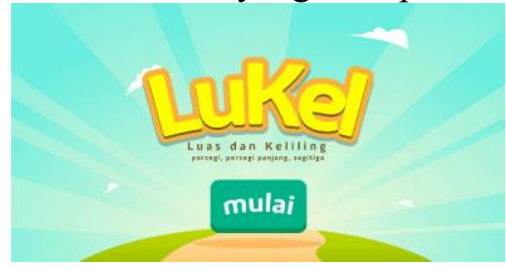

\section{Gambar 1. Halaman Awal dan Pembuka Cerita}

Materi yang digunakan adalah luas dan keliling persegi, persegi panjang, serta segitiga. Materi tersebut diberikan dengan didesain seperti suatu cerita seperti yang terlihat pada Gambar 2.
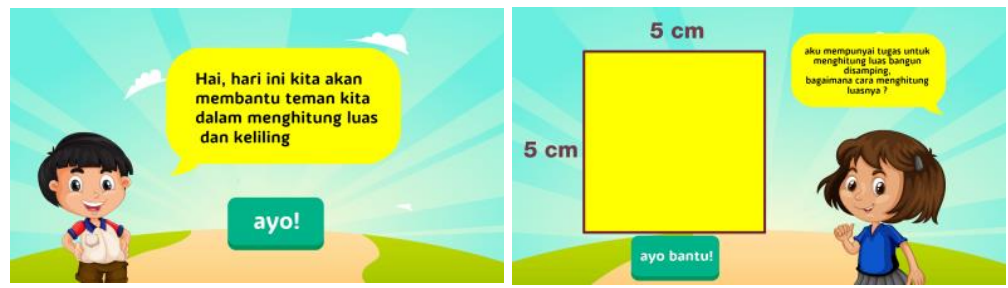

Gambar 2. Materi tentang Persegi

Berdasarkan Gambar 2, terlihat bahwa materi diberikan dengan memberikan soal terlebih dahulu kepada peserta didik. Hal ini ditunjukkan dengan kalimat "aku mempunyai tugas untuk menghitung luas bangun disamping, bagaimana cara menghitung luasnya?"

Setelah memilih tombol 'ayo bantu' akan muncul perintah seperti pada Gambar 3 berikut. Gambar 3 tersebut menunjukkan bahwa peserta diminta untuk membuat persegi dengan ukuran yang sama seperti pada soal, lalu membuat persegi-persegi berukuran $1 \mathrm{~cm}^{2}$ yang nantinya akan digunakan untuk menutupi persegi mula-mula.

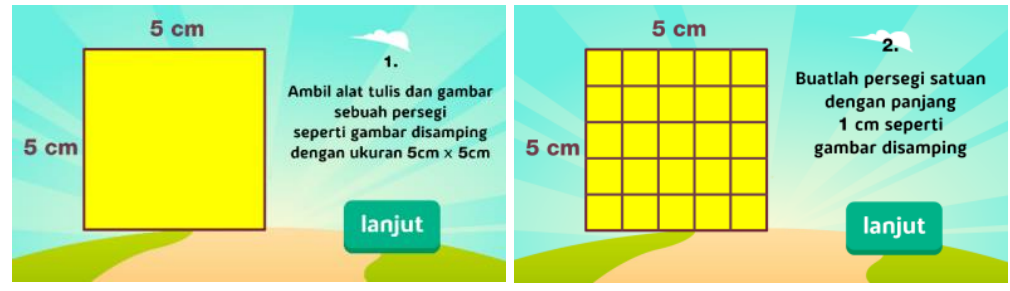

Gambar 3. Tampilan Awal Materi Persegi

Setelah memilih tombol 'lanjut', akan muncul tampilan seperti Gambar 4. Gambar 4 memperlihatkan bahwa terdapat pertanyaan yang harus dijawab oleh peserta didik. Mereka dapat menjawab pertanyaan tersebut dengan melakukan input secara langsung. Misalkan peserta didik ingin menjawab 25 , dia dapat mengetik ' 25 ' di tempat yang telah disediakan. Selanjtnya, dapat dipilih tombol 'oke!'. 


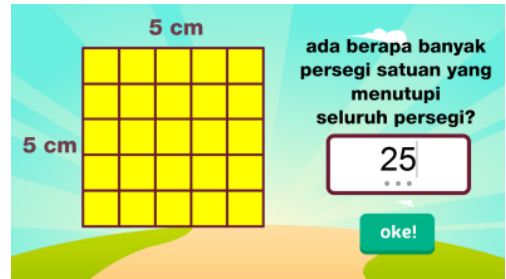

\section{Gambar 4. Tampilan Pertanyaan Materi Persegi}

Apabila jawaban peserta didik salah, akan muncul keterangan "jawaban kamu salah" sedangkan apabila jawaban peserta didik benar, akan ditampilkan penjelasan bahwa banayaknya persegi satuan yang menutupi persegi mula-mula menyatakan luas. Berikut adalah gambar yang menunjukkan hal tersebut.
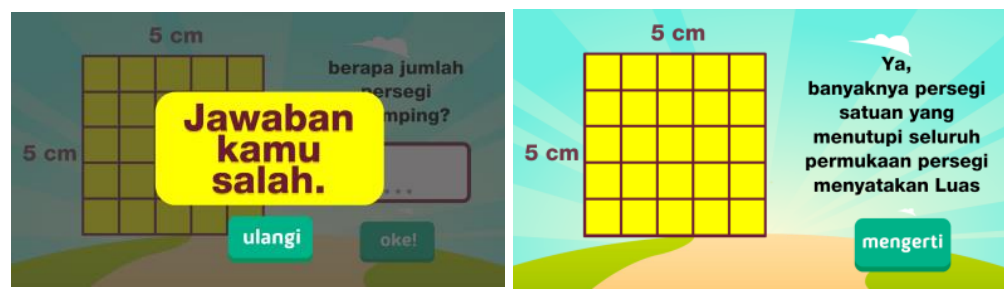

Gambar 5. Respon atas Pilihan Jawaban Peserta Didik

Pada tampilan berikutnya, akan muncul pertanyaan yang lain. Pertanyaan tersebut berbunyi "ada berapa banyak persegi yang menutupi salah satu sisi persegi?". Pertanyaan ini bertujuan untuk membantu peserta didik dalam menemukan rumus luas persegi sama dengan sisi dikali sisi. Untuk membantu peserta didik dalam memahami soal yang dimaksud, peneliti mendesain agar ada perubahan warna pada persegi-persegi satuan yang menutupi salah satu sisi persegi seperti yang terlihat pada Gambar 6.

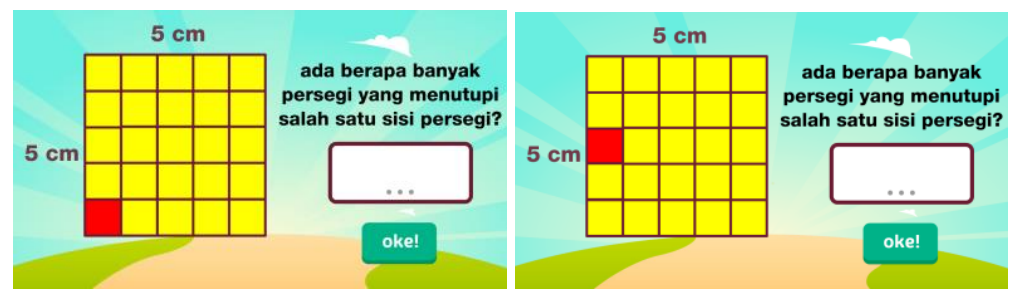

Gambar 6. Pertanyaan Kedua Materi Persegi

Apabila peserta didik menjawab dengan benar, akan muncul tampilan seperti Gambar 7. Gambar 7 berisi penjelasan bahwa luas persegi dapat dicari dengan menggunakan rumus $\mathrm{L}=\mathrm{s} \times \mathrm{s}$.
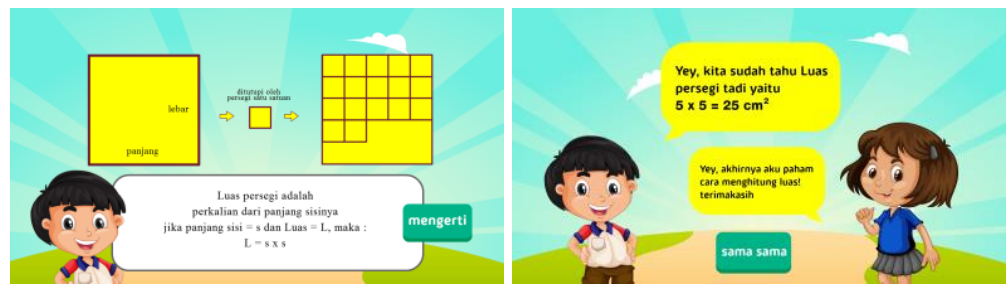

Gambar 7. Penjelasan Luas Persegi

Setelah peserta didik belajar tentang materi luas persegi, mereka dapat memilih untuk belajar tentang keliling persegi. Pada tahap ini, peserta didik belum dapat memilih untuk belajar tentang luas dan keliling persegi panjang ataupun segitiga. Berikut adalah gambar yang menunjukkan hal tersebut. 


\section{Gambar 8. Tampilan Setelah Menyeelsaikan Materi Persegi}

Apabila peserta didik memilih tombol 'keliling', akan muncul tampilan seperti Gambar 9. Gambar 9 berisi masalah matematika yang berkaitan dengan keliling persegi.

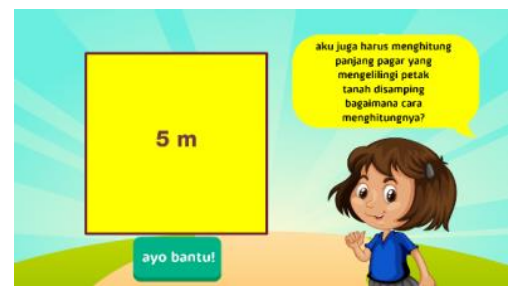

\section{Gambar 9. Materi Keliling Persegi}

Penyajian materi keliling persegi didesain mirip dengan penyajian materi luas persegi. Peserta didik diberikan beberapa pertanyaan yang bertujuan untuk membantu peserta didik memahami apa itu keliling dan bagaimana menghitung keliling persegi. Berikut adalah gambar yang menunjukkan hal tersebut.
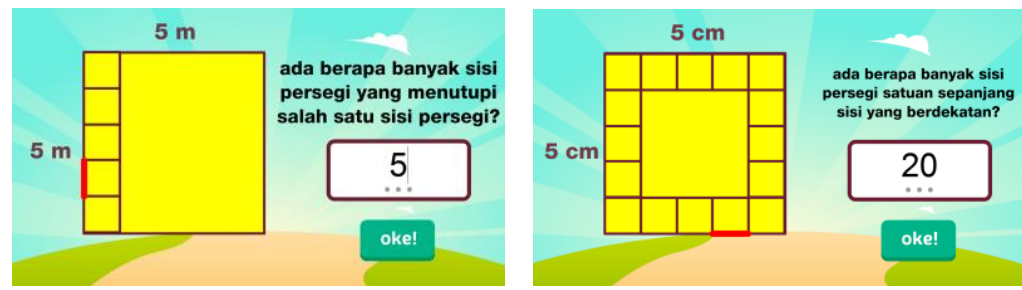

Gambar 10. Tampilan Materi Keliling Persegi

Materi tentang keliling diakhiri dengan penguatan apa itu keliling dan rumus untuk mencari keliling persegi seperti yang terlihat pada gambar 11 .

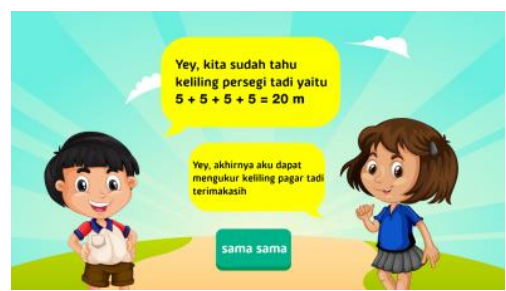

Gambar 11. Materi Keliling Persegi

Penyajian materi luas dan keliling persegi panjang dan segitiga dilakukan dengan cara yang sama dengan penyajian materi luas dan keliling pada materi persegi. Materi disajikan dengan memberikan masalah/aktivitas terlebih dahulu yang berkaitan dengan luas atau keliling persegi panjang dan segitiga seperti yang terlihat pada Gambar 12. 

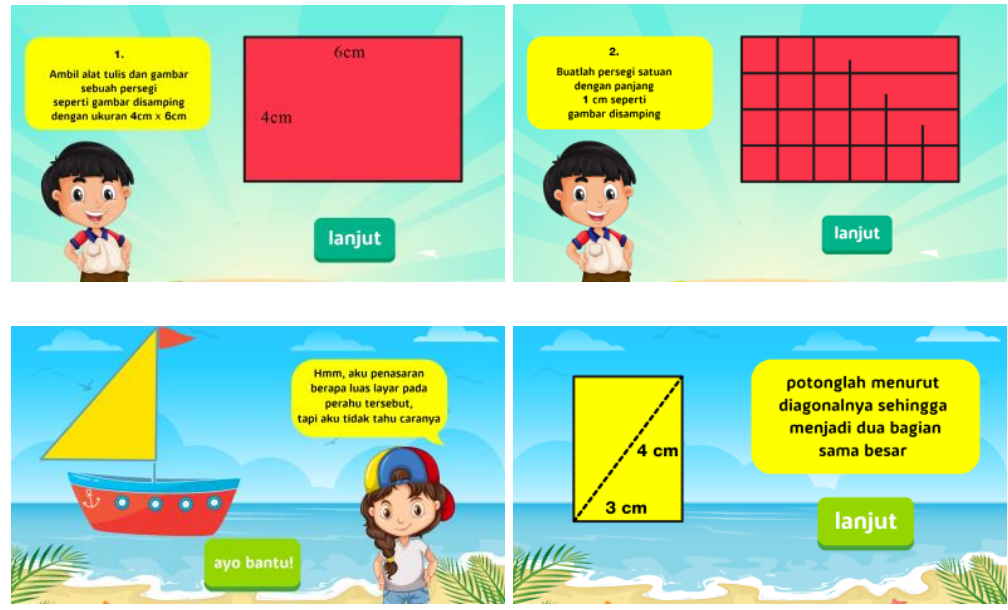

Gambar 12. Materi Persegi Panjang dan Segitiga

Setelah peserta didik membaca masalah tersebut, peserta didik akan diberikan pertanyaanpertanyaan yang terkait dengan luas dan keliling persegi panjang serta segitiga seperti yang terlihat pada Gambar 13.
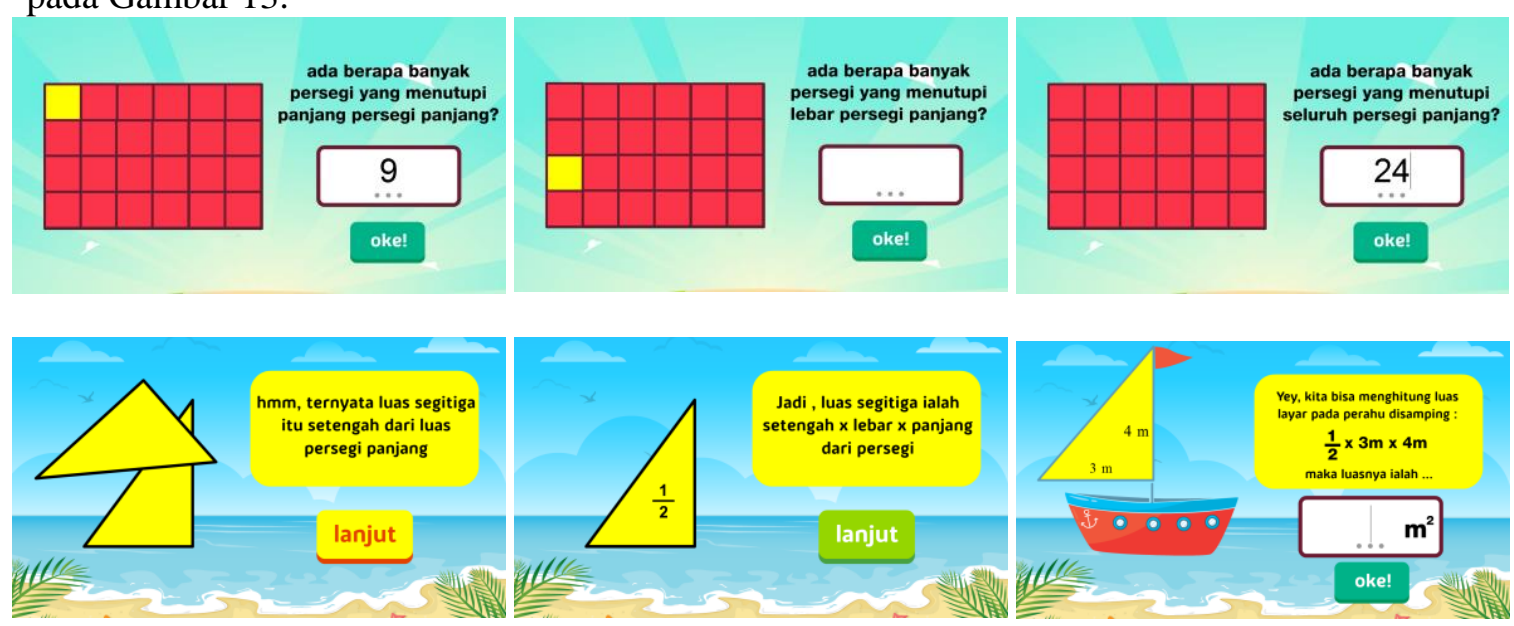

Gambar 13. Pertanyaan Pada Materi Persegi Panjang dan Segitiga

Selanjutnya, apabila peserta didik dapat menjawab pertanyaan dengan benar, akan muncul penjelasan terkait dengan luas atau keliling persegi panjang dan segitiga.
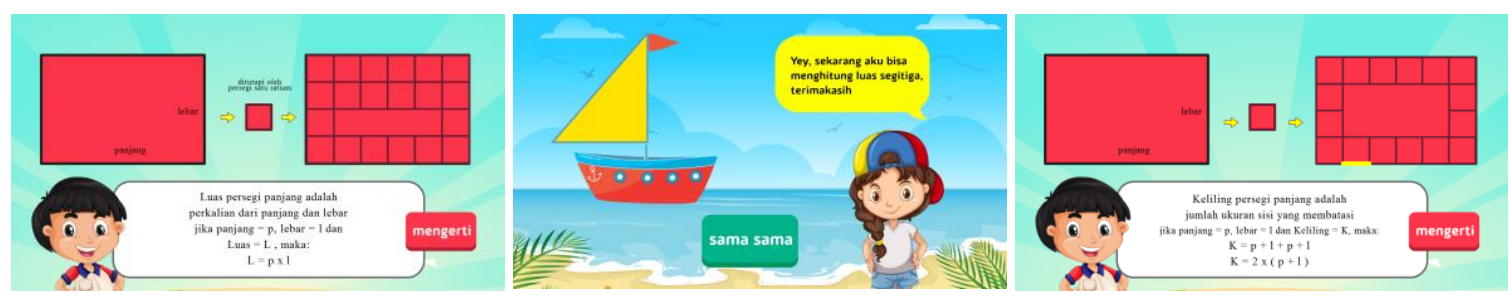

Gambar 14. Penjelasan Materi Persegi Panjang dan Segitiga

3. Latihan Soal

Latihan soal dapat dipilih oleh peserta didik setelah menyelesaiakn keseluruhan materi tentang luas dan keliling. Apabila peserta didik ingin mencoba latihan soal tersebut, dapat dipilih tombol 'ayo berlatih' seperti yang terlihat pada Gambar 15 di bawah ini. 


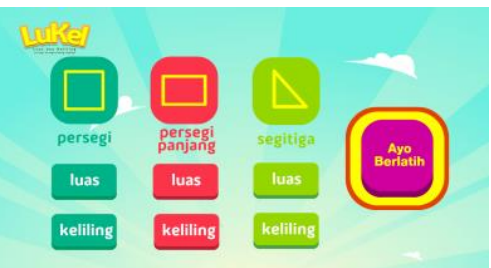

\section{Gambar 15. Tampilan Setelah Menyelesaikan Materi Luas dan Keliling}

Latihan soal terdiri dari 15 pertanyaan dengan tingkat kesulitan yang bervariasi. Sama seperti saat penyajian materi tentang luas dan keliling, soal diberikan secara berurutan. Jawaban soal didesain tidak pilihan ganda (isian singkat) agar peserta didik tidak dapat menghafal jawaban atau mengerjakan secara sembarangan. Peserta didik dapat lanjut ke soal berikutnya apabila dapat menjawab soal dengan benar. Apabila jawabannya salah, peserta didik harus mengulai mengerjakan soal tersebut. Berikut adalah gambar yang menunjukkan hal tersebut.

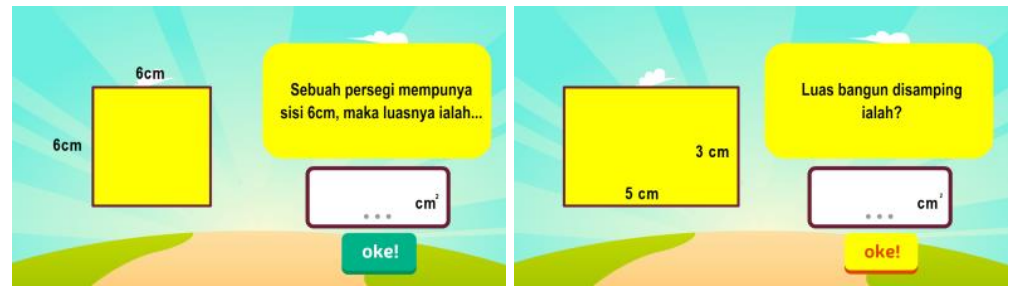

Gambar 16. Contoh Soal

\section{Tahap Pengembangan (Develop)}

Tahap pengembangan terdiri dari tahap validasi media dan tahap uji coba media. Validasi media terdiri dari validasi media dan validasi materi. Validasi media dilakukan pada aspek tampilan dan aspek tulisan. Hasil validasi media dapat dilihat pada Tabel 1 berikut.

Tabel 1. Hasil Validasi Media

\begin{tabular}{ll}
\hline \multicolumn{1}{c}{ Kriteria atau indikator yang dinilai } & Skor rata-rata \\
\hline Aspek Tampilan & \\
\hline Gambar dan animasi menarik & 4 \\
Ukuran tulisan, gambar, dan animasi sesuai & 4 \\
Tata letak tulisan, gambar, dan animasi sesuai & 4 \\
Media sesuai dengan karakter peserta didik & 3 \\
\hline Aspek Tulisan & \\
\hline Tulisan mudah dibaca & 4 \\
Kalimat mudah dimengerti & 3 \\
Warna yang digunakan sesuai & 4 \\
\hline
\end{tabular}

Berdasarkan hasil validasi media nampak bahwa dalam aspek tampilan memiliki kecenderungan sangat baik dengan skor 4. Media masih dinilai baik untuk aspek kesesuaian dengan karakteristik peserta didik dan kalimat yang mudah dimengerti, hal ini lebih karena alasan kesehatan apabila penggunaan media yang berbasis komputer terlalu lama akan berpengaruh pada kesehatan mata peserta didik dan kecenderungan usia anak-anak meihat dari jarak dekat.

Pada uji validasi media, dilakukan revisi sebanyak dua kali. Revisi tersebut meliputi penambahan menu kredit pada homepage, perubahan kalimat yang digunakan, penambahan keterangan benar, penambahan background musik, dan penambahan animasi. Berikut adalah perbandingan tampilan sebelum dan sesudah media direvisi. 

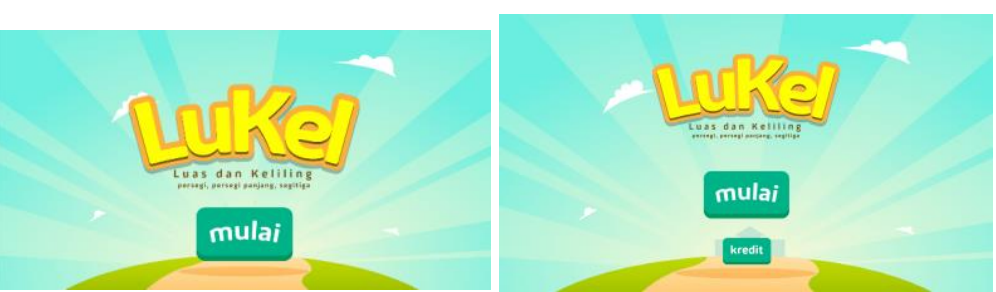

Gambar 17. Tampilan Homepage Sebelum dan Sesudah Revisi
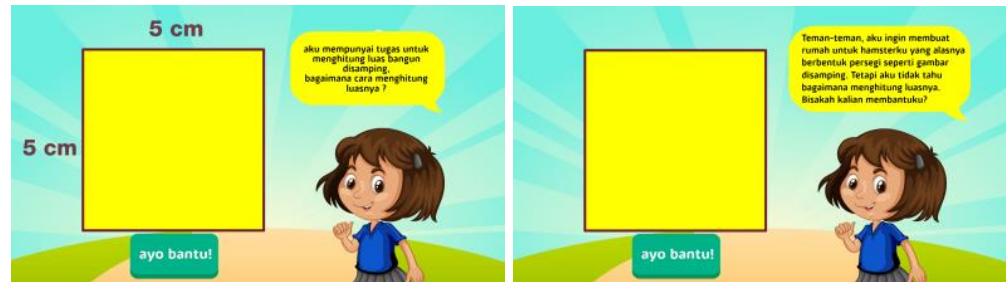

Gambar 18. Tampilan Masalah Awal Sebelum dan Sesudah Revisi
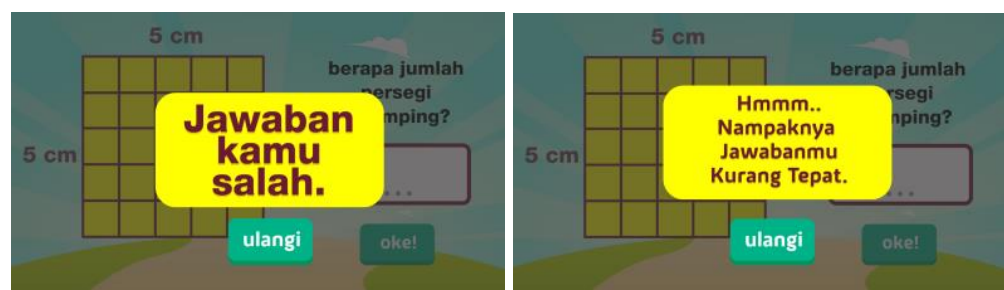

Gambar 19. Respon Terhadap Jawaban Peserta Didik Sebelum dan Sesudah Revisi
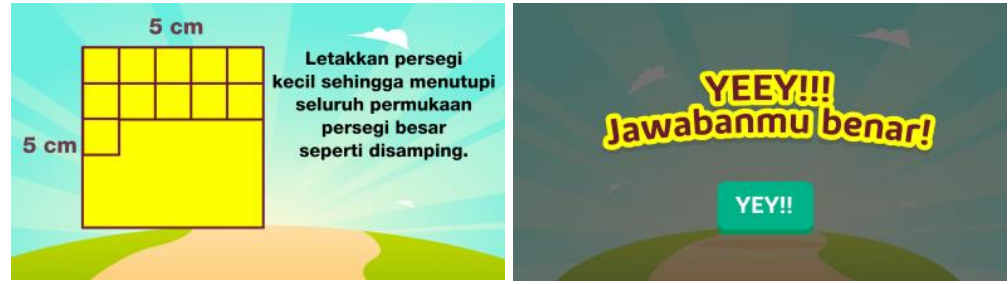

Gambar 20. Penambahan Beberapa Tampilan

Hasil validasi materi dapat dilihat pada Tabel 2 di bawah ini.

Tabel 2. Hasil Validasi Materi

\begin{tabular}{lc}
\hline \multicolumn{1}{c}{ Kriteria yang dinilai } & Skor rata-rata tiap aspek \\
\hline Aspek Kurikulum & \\
\hline Materi sesuai dengan kompetensi dasar & 3 \\
Kebenaran konsep materi ditinjau dari konsep keilmuan & 4 \\
\hline Apek Penyajian Materi & 4 \\
\hline Konsep yang dijabarkan sudah tepat & 4 \\
Materi terorganisasi dengan baik & 4 \\
Materi sesuai dengan perkembangan kognitif peserta didik & 4 \\
Materi terkait dengan kehidupan sehari-hari & \\
\hline Aspek Evaluasi & 4 \\
\hline Evaluasi sesuai dengan materi dan tujuan pembelajaran & 4 \\
Bentuk evaluasi soal sesuai dengan konsep yang disajikan & 3 \\
Tingkat kesulitan soal & 4 \\
Soal bervariasi & \\
\hline
\end{tabular}

Berdasarkan tabel 2 di atas, diperoleh skor kevalidan sebesar 3 atau 4 untuk setiap indikator dengan rata-rata 3,8. Hal ini menunjukkan bahwa media tersebut valid. 
Setelah media dikatakan valid, media siap untuk di uji coba. Uji coba dilakukan di SD Negeri Mardirahayu pada hari Jumat tanggal 27 Juli 2018 dengan 60 peserta didik sebagai pesertanya. Uji coba dilakukan untuk mengetahui respon peserta didik terhadap media yang telah dikembangkan. Pada uji coba ini, peserta didik diminta menilai media yang telah dikembangkan dengan mengisi angket yang telah disediakan. Penilaian didasarkan pada aspek tampilan dan aspek fungsi. Hasil analisis respon peserta didik terhadap media yang dikembangkan dapat dilihat pada tabel 3 .

Tabel 3. Data Respon Peserta Didik

\begin{tabular}{ll}
\hline \multicolumn{1}{c}{ Kriteria yang dinilai } & Skor rata-rata tiap aspek \\
\hline Aspek Tampilan & \\
\hline Warna, tulisan, gambar, dan animasi menarik & 3,45 \\
Ukuran animasi, gambar, dan tulisan sesuai & 3,55 \\
Tata letak animasi, gambar dan tulisan sudah baik & 3,5 \\
Media mudah untuk dioperasikan & 3,65 \\
\hline Aspek Fungsi & \\
\hline Media mampu memberikan sarana belajar dan berlatih & 3,5 \\
materi luas dan keliling & \\
Media mampu memotivasi saya untuk belajar matematika & 3,45 \\
\hline
\end{tabular}

Berdasarkan Tabel 3, Aspek tampilan dinilai baik dan cenderung sangat baik, siswa memberikan nilai tinggi pada kemudahan pengoprasian media, sedangkan pada aspek fungsi media dinilai mampu memotivasi siswa untuk belajar matematika dengan skor 3,45 dalam katagori baik.

\section{Penyebaran (Disseminate)}

Pada tahap ini, media yang telah dikembangkan disebarluaskan atau dipromosikan. Penyebaran media tersebut dilakukan secara terbatas kepada guru SD Negeri Mardirahayu.

Hasil penelitian menunjukkan bahwa media pembelajaran berbasis Macromedia Flash yang dikembangkan valid. Hasil respon peserta didik menunjukkan bahwa media yang telah dikembangkan menarik dan membuat peserta didik lebih tertarik untuk belajar matematika. Hasil tersebut sejalan dengan beberapa hasil penelitian yang dilakukan Kusuma, Nasution, \& Anggoro (2018); Kumala, (2015); dan Nugraha, (2017) bahwa pembelajaran dengan menggunakan media interaktif baik itu Macromedia Flash maupun adobe flash mampu membuat peserta didik lebih tertarik menggunakannya sebagai media pembelajaran.

Media pembelajaran berbasis Macromedia Flash yang dikembangkan tidak hanya memberikan materi dan latihan soal kepada peserta didik, namun juga memungkinkan peserta didik untuk terlibat aktif dalam menggunakan media tersebut. Peserta didik diberikan kesempatan untuk menginput jawaban secara langsung sehingga peserta didik benar-benar belajar terhadap materi atau soal yang diberikan.

Kelebihan media berbasis Macromedia Flash yang telah dikembangkan dalam penelitian ini adalah 1) memiliki tampilan dan animasi yang menarik, 2) materi luas dan keliling yang diberikan diberikan dengan pendekatan pemecahan masalah, 3) memfasilitasi peserta didik untuk terlibat aktif pada saat menggunakan media dengan melakukan input jawaban secara langsung, dan 4) latihan soal yang diberikan lengkap dan memiliki tingkat kesulitan yang beraneka ragam.

Namun demikian, media ini juga memiliki beberapa kekurangan, yaitu: 1) masih terbatas pada materi luas dan keliling persegi, persegi panjang serta segitiga, dan 2) hanya dapat dijalankan dengan menggunakan komputer. 


\section{SIMPULAN DAN SARAN}

Media pembelajaran yang dikembangkan valid dan mampu menarik minat peserta didik untuk belajar matematika. Media ini masih terbatas untuk komputer, peneliti berikutnya dapat mengembangkan media serupa yang dapat dijalankan menggunakan smartphone.

\section{UCAPAN TERIMAKASIH}

Mengucapkan terimakasih kepada Kepala Sekolah, Guru Kelas dan Siswa SD Mardirahayu 01 dan 02 Ungaran, juga kepada Tri Nova Hasti Yunianta, M.Pd. sebagai validator materi dan Dr. Henny Dewi Koeswanti, M.Pd. sebagai validator media serta UKSW yang telah membiayai penelitian ini berdasarkan Keputusan Rektor No. 085/Penel/Rek./4/V/2018.

\section{DAFTAR PUSTAKA}

Ahern, T. C. (2016). AWaterfall Design Strategy for Using Social Media for Instruction.

Amir, A. (2014). Pembelajaran Matematika SD dengan Menggunakan Media Manipulatif. Forum Paedagogik, 6(1):72-89

Arda, S. S., \& Darsikin. (2015). Pengembangan Media Pembelajaran Interaktif Berbasis Komputer untuk Peserta didik SMP Kelas VIII. e-Jurnal Mitra Sains, 3(1), 69-77

Astuti, A., \& Leonard. (2012). Peran Kemampuan Komunikasi Matematika Terhadap Prestasi Belajar Matematika Peserta didik. Jurnal Formatif, 2(2):102-110

Hamdu, G., \& Agustina, L. (2011). Pengaruh motivasi belajar siswa terhadap prestasi belajar IPA di sekolah dasar. Jurnal penelitian pendidikan, 12(1), 90-96.

Hamdu, G., \& Agustina, L. (2011). Pengaruh motivasi belajar siswa terhadap prestasi belajar IPA di sekolah dasar. Jurnal penelitian pendidikan, 12(1), 90-96.

Journal of Educational Technology Systems, 44 (3), 332-345.

Khairani, M., \& Febrinal, D. (2016). Pengembangan Media Pembelajaran Dalam Bentuk Macromedia Flash Materi Tabung Untuk SMP Kelas IX. Jurnal Ipteks Terapan, 10 (2), 95-102.

Kumala, W. S. J. (2015). Pembuatan Media Pembelajaran Interaktif Pengenalan Benda Berbasis Game untuk Anak Sekolah Dasar Kelas I. CALYPTRA, 4(1), 1-14.

Kusuma, R. D. F. D., Nasution, S. P., \& Anggoro, B. S. (2018). Multimedia Pembelajaran Matematika Interaktif Berbasis Komputer. Desimal: Jurnal Matematika, 1(2), 191-199.

Kusumadewi, O. d. (2013). Keefektifan CTL Berbantuan Macromedia Flash Terhadap Kemampuan Berpikir Kritis pada Materi Segiempat. Jurnal Kreano, 4 (1), 57-63.

Masykur, R., Nofrizal., \& Syazali, M. (2017). Pengembangan Media Pembelajaran Matematika dengan Macromedia Flash. Al-Jabar: Jurnal Pendidikan Matematika, 8(2), 177-186.

Nugraha, R. G. A. (2017). Interactive Media Development for Second Grade Elementary Students Thematic Learning Using Adobe Flash CS4 Professional. Scholaria: Jurnal Pendidikan Dan Kebudayaan, 7(2), 94-105.

Prihandoko, A. C. (2006). Pemahaman dan Penyajian Konsep Matematika Secara Benar dan Menarik. Jakarta: Depdiknas.

Putra, R. A., \& Manoy, J. T. (2016). Pengembangan Media Pembelajaran Berbasis Information and Communication Technology dengan Software Macromedia Flash 8 pada Materi Segiempat. MATHEdunesa, 3(5).

Safitri, M. (2013). Pengembangan Media Pembelajaran Matematika Pokok Bahasan Segitiga Menggunakan Macromedia Flash Untuk Peserta didik Kelas VII SMP. Jurnal Pendidikan, $14(2), 62-72$. 
Pengembangan Media Pembelajaran Matematika Berbasis Macromedia Flash Materi Luas Dan

Keliling Untuk Meningkatkan Motivasi Belajar Siswa (Krisma Widi Wardani, Danang Setyadi)

Sardiman, A. M. (2001). Interaksi dan Motivasi dalam belajar Mengajar. Jakarta: Raja Grafindo Persada.

Setyadi, D., \& Qohar, A. (2017). Pengembangan Media Pembelajaran Matematika Berbasis Web pada Materi Barisan dan Deret. Jurnal Kreano, 8(1), 1-7

Sinurat, M., Syahputra, E., \& Rajagukguk, W. (2015). Pengembangan Media Pembelajaran Berbantuan Program Flsh Untuk Meningkatkan Kemampuan Matematik Peserta didik SMP. Jurnal Pendidikan Tabularasa, 12(2)

Sukamto, E. B. (2015). Pengembangan Media Pembelajaran Kimia Berbantuan Komputer Dengan Program Macromedia Flash 8. Jurnal Inovasi Teknologi Pendidikan, 2 (2), 143-156.

Thiagarajan, S. (1974). Instructional development for training teachers of exceptional children: A sourcebook.

Tyanto, E. L., \& Manoy, J. T. (2013). Pengembangan Media Pembelajaran Matematika Berbasis Adobe Flash Profesional CS 6 Dengan Memperhatikan Fungsi Kognitif Rigorous Mathematical Thinking (RMT) Pada Materi Melukis Segitiga. MATHEdunesa, 2(3).

Umam, K., \& Yudi. (2016). Pengaruh Menggunakan Software Macromedia Flash 8 Terhadap Hasil Belajar Matematika Peserta didik Kelas VIII. KALAMATIKA, 1(1): 84-92.

Wardani, K. W. (2012). Efektivitas Penerapan Permainan Menggunakan Aturan Terhadap Peningkatan Hasil Belajar Matematika Kelas IV Semester I di SD Negeri Kawengen 02 Ungaran Timur Kabupaten Semarang Tahun Ajaran 2011/2012 (Doctoral dissertation, Doctoral dissertation, Program Studi Pendidikan Guru Sekolah Dasar FKIP-UKSW).

Waskito, D. (2014). Media Pembelajaran Interaktif Matematika Bagi Sekolah Dasar Kelas 6 Berbasis Multimedia. Speed Journal, 11(3), 59-65.

Wicaksono, S. (2016). The Development Of Interactive Multimedia Based Learning Using Macromedia Flash 8 In Accounring Course. Journal of Accounting and Business Education, 1(1), 122-139

Winkel, W. S. (1983). Psikologi pendidikan dan evaluasi belajar. Gramedia.

Yudi, K. U. (2016). Pengaruh Menggunakan Software Macromedia Flash 8 Terhadap Hasil Belajar Matematika Siswa Kelas VIII. Kalamatika: Jurnal Pendidikan Matematika , 1 (1), 84-92. 